\title{
Clinical anatomy aspects of functional 3D training - case study
}

\author{
Dalibor Pastucha ${ }^{a \#}$, Radka Filipcikova ${ }^{\mathrm{bt}}$, Marcela Bezdickova ${ }^{\mathrm{b}}$, Zdenka Blazkova $^{\mathrm{b}, \mathrm{c}}$, Ivana Obornac, Jana Brezinova ${ }^{\mathrm{b}}$, \\ Libor Machalek ${ }^{b}$, Eliska Sovova ${ }^{a}$, Vit Cajka ${ }^{a}$, Jan Bajorek ${ }^{a}$
}

\begin{abstract}
Introduction. Functional 3D training originating in rehabilitation and physiotherapy routines, is modelled on the basis of a patient's functional impairment and muscle function test results. 3-D functional rehabilitation comprises two key components. The first is three-dimensional movements of the body and the second is restoration of function, The aim of 3D training is not only to improve physical fitness and muscular coordination, it is recommended for all age groups regardless of health status. The aim of this review is to highlight the main principles, roles and methods of 3D functional training from a clinically-anatomical perspective and its application in clinical practice. Second, we present a case study of $3 d$ training in an obese boy.

Methods. Database search using the lemmatization method and data bases: Web of Knowledge, Web of Science, UpToDate, PubMed and Google Scholar for the years 2005-2011.

Results and Conclusions. Functional 3D training is an effective method for, among others, strengthening the postural muscles of the human body, increasing articular stability, strengthening the ligaments and stability of muscle groups,especially the back muscles and for improving lung capacity. The method of functional training is of considerable significance in activating the pelvic floor muscles and the pelvic-trochanteric muscles for gynegymnastics and incontinence prevention. It has application in the prevention of falls in patients with neurodegenerative diseases and, as shown below, in the therapy of obesity.
\end{abstract}

Key words: 3D training, resistance training, obesity, children

Received: July 22, 2011; Accepted with revision: January 25, 2012; Available online: February 28, 2012 http://dx.doi.org/10.5507/bp.2012.016

aDepartment of Sport Exercise Medicine and Cardiovascular Rehabilitation, University Hospital Olomouc and Faculty of Medicine and
Dentistry, Palacky University Olomouc, Czech Republic
${ }^{b}$ Department of Anatomy, Faculty of Medicine and Dentistry, Palacky University Olomouc
'Department of Gynecology and Obstetrics, Faculty of Medicine and Dentistry, Palacky University Olomouc
"Authors contributed equally to the work
Corresponding author:Dalibor Pastucha, e-mail: dalibor.pastucha@fnol.cz

\section{INTRODUCTION}

In many popular and professional publications, the term functional training, 3D training or spatial exercise is often encountered. Functional training from a clinicalanatomical perspective and its application in clinical practice is dependent on a sound knowledge of clinical anatomy. Functional training highlights a need for furthering anatomical knowledge in the postgraduate education of physicians from various fields of clinical practice, e.g. in sports medicine and physiotherapy ${ }^{1}$.

Functional training is a suitable alternative to power exercise and stems from rehabilitation and physiotherapy routines. It is modelled on the basis of the patient's functional impairment and muscle function test results. The aim of 3D training is not only to improve physical fitness and muscular coordination, it is also recommended for all age groups in healthy as well as indisposed individuals. Many of its exercises are based on common everyday activities which require coordination and fluid movement to a greater or lesser extent, such as walking, running, lifting an object, etc. During such daily activities we call into action many muscle groups, with increased demands on neuromotor coordination and maintenance of body posture ${ }^{2}$.

We have been using 3D training in our Pediatric Clinic for the therapy of obese children. We believe it has wider application in various clinical fields. However, search of the traditional medical data bases reveals a dearth of information. This review aims to provide elementary information on the principles, roles, methods and applicability of 3D training.

\section{METHODS}

Database search using the lemmatization method and data bases: Web of Knowledge, Web of Science, UpToDate, PubMed and Google Scholar for the years 2005-2011. Given the dearth of information in traditional medical databases, these were available options.

We examined studies that focused on the possibilities of using functional 3D training in clinical practice based on implementing the anatomical findings. As this is a fairly new method, so far not used as standard in general clinical practice, we were only able to carry out analysis 
of a limited number of studies. Our experiences are presented in a case report which correlates with available references.

\section{RESULTS}

\section{Functional training}

Functional training is a synergetic involvement of several muscle groups simuo̊taneously enabling training that is more productive. The most commonly used tools for 3D training are: free pulleys, single-handed weights, a medicine ball, a large ball, exercise bands, imbalance pads, bags with sand or water, GRAVITY program in rehabilitation on Power Tower system and the very effective army navy system TRX- Training Resistance Exercise. TRX is shown in Fig. 1. The scheme is described according safety principles of the producer ${ }^{3}$.

A prerequisite for this training is quality of perceived movement rather than isolated muscle function. During activities of daily living, the body does not move in isolated patterns. It moves as an integrated unit, be it functional or dysfunctional It strives to create such individual structure of exercises that help carry out common daily activities with greater efficiency and lower risk of injury. At the same time, the training leads to greater muscular balance and strengthening of the spine stabilization system; it has positive impact on articular stability and significantly contributes to preventing musculoskeletal injuries. Functional training restores and enhances the way the body performs everyday physical activities and memorizes such muscular functions ${ }^{4-6}$.

All these muscles create only a single subsystem of the deep stabilization system, known as active. The passive element is formed by the vertebrae, ligaments and intervertebral discs. The stability of the spine is impacted by the neural element via the afferent supply from receptors, and subsequent control of the active element ${ }^{7}$. Imbalance of one of their elements can cause a) immediate compensation - function normalisation, b) long-term adaptation process of one or several subsystems - with function normalisation, but with a change in the stabilization system, c) disabling of one or several elements of some system - with total imbalance, which leads to e.g. the painful syndrome of low back pain (LBP) - in these patients we find variations in stabilization of muscle function in comparison with the development model of stabilization $^{8}$. In patients with LBP, greater damage in the thoracic area of Musculus erector spinae (MES) in comparison to the lumbar area of MES was proven with an EMG examination ${ }^{9}$. Targeted interference of the deep stabilization system in chronic vertebrogenic difficulties is therefore the main therapeutic procedure and enables targeted focus on the damaged area. One caveat is that opinions on the character of these exercises differ ${ }^{10,11}$.

The therapeutic methods can be used not only as part of physiotherapy, for the therapy of already developed muscular and neuromuscular imbalance, but also as prevention in reconditioning and training of athletes, especially in sports with significantly asymmetric degree of load in the lumbar spine area. This fact was confirmed by the Renkawitz's study, on tennis players and proved the development of neuromuscular imbalance at the $\mathrm{L} 2$ and L4 level in connection with asymmetric load, exhibited by altered electric activity of MES measured by means of EMG examination ${ }^{12}$.
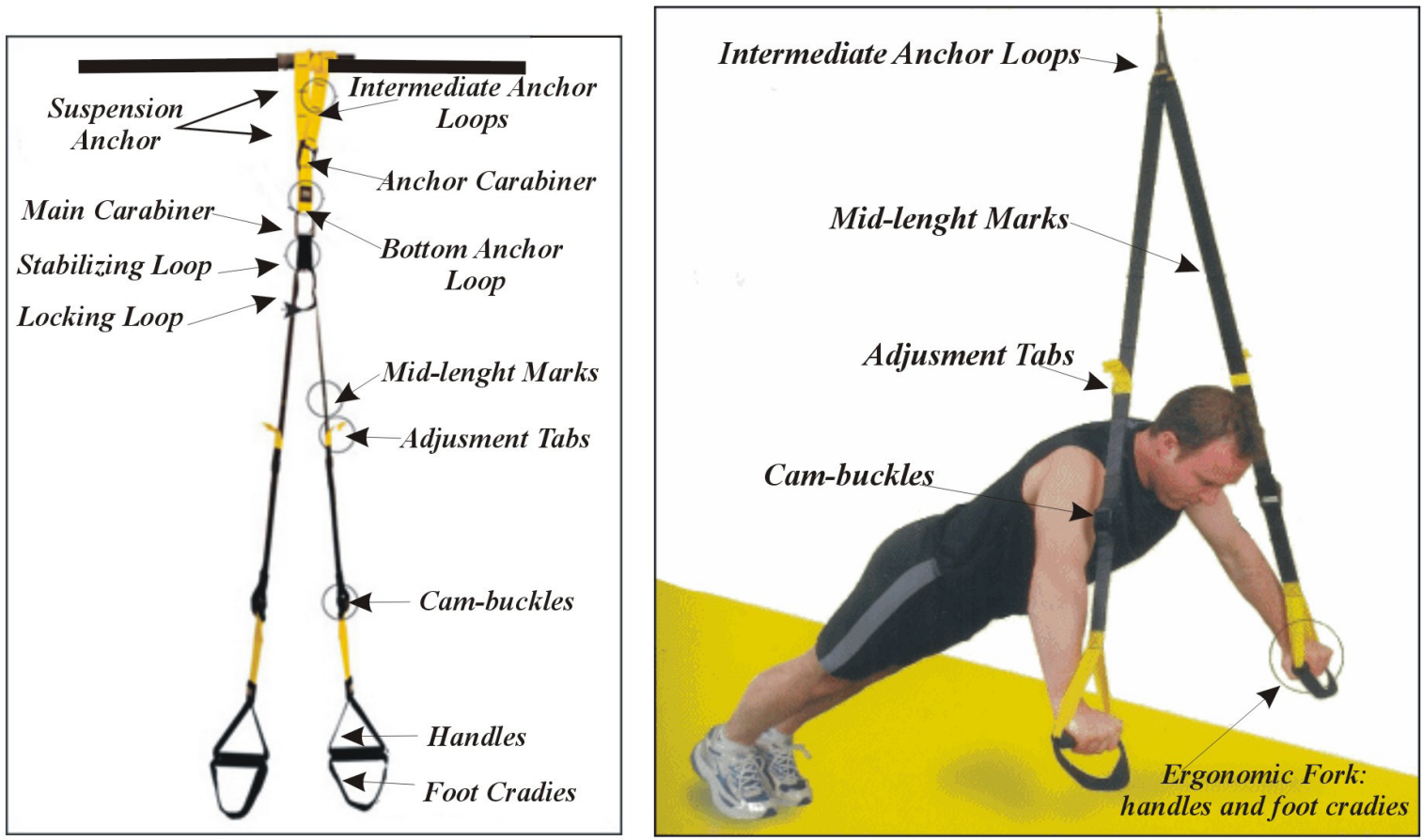

Fig. 1. TRX-Training Resistance Exercise. 
The National Academy of Sports Medicine (NASM), which was founded in 1987 in Chicago, specifies functional training as a modern method of exercise involving coordinated precision movement in the stages of acceleration, deceleration and stabilization of the postural muscle groups in all three axes of the Cartesian coordinate system $^{13}$.

Schofftal (2010) found a significantly greater muscle activity examined with electromyographic (EMG) of the internal obliques (IOs), during a prone V-up on TRX compared to various abdominal isometric exercises ${ }^{14}$.

Since physical training can be an important method for preventing falls e.g. in patients with neurodegenerative disease, and given the positive effects of exercise on healthy articular cartilage it can be protective against the onset of osteoarthrosis ${ }^{15-17}$.

Functional training performed on unstable surfaces might best be utilized during after injury rehabilitation or during in-season training to maintain core endurance levels and reduce the incidence of injuries. Fitzgerald, Axe, and Snyder-Mackler found that performance of wobble board exercises improved rehabilitation outcomes in subjects with anterior cruciate ligament (ACL) rupture ${ }^{18}$.

During the exercise, we usually work with the weight of our own body, many muscle groups are connected in one fluid exercise movement and we check the correct posture of body's centre of gravity (COG), flexibility and coordination of muscle groups, and especially the posture and operation of body's deep stabilization system, i.e. postural muscles during training ${ }^{15-17}$.

The main quantitative physical forces affecting the human body are of three types: gravity, the strength of muscles and the "third factor", which is known as the force of physiological impact and deformation forces. The effect of these forces on a specific body element is concentrated on a single point, the body's centre of gravity. The position of such centre of gravity is what absolutely determines the stability of a body ${ }^{4-6}$ and enables us to study the course of movement and conditions of body posture ${ }^{19-21}$. Change in the body posture or manifestations of instability are, according to the law of action and reaction, balanced by tonic correction of muscles, whereby upon incorrect involvement of compensation muscles or upon muscle function impairment, we must renew correct stability of the body through exercise and thereby retroactively effect the body's centre of gravity.

The body's centre of gravity has no permanent place as it oscillates according to the movement of its parts 21 . The centre of gravity in basic anatomical position of rest is in the median line at L3-L4 in women and L2-L3 in men, $4.5-5.5 \mathrm{~cm}$ ventrally from facies anterior corporis vertebrae $22-24$.

If the body's centre of gravity is the foundation of body's stability, such stability is then increased by posture, muscle strength and increased mass of the body erectors. One of the most significant ones, activated to the maximum extent during functional training, is musculus erector spinae (MES) $\left(\right.$ ref..$\left.^{25}\right)$.

MES is the most extensive and voluminous of the deep stabilization system muscles, the main function of which is erecting the torso. It belongs to postural muscles that control and impact active movements of the spine, apart from anteflexion due to the antagonist activity of the abdominal muscles ${ }^{24,26}$.

As for its function, MES is responsible for maintaining stability of the spine and as bilateral action, for erecting the spine and backward bending of the head. As unilateral action, it helps in bending of the spine and rotation to the side of an acting muscle. It participates practically in all fundamental and critical movements required for movement of an individual ${ }^{22,27,28}$.

Deep dorsal muscles belong to a group of indigenous muscles and they can be divided according to the layers in a dorsal-ventral direction into (Fig.1) $\left(\right.$ ref. $^{25}$ ).

MES is in intense and constant interaction with all layers of the dorsal muscles and impacts the function and efficiency of the abdominal muscles and participates in them. The system of work and stabilisation of abdominal muscles was demonstrated by Kapanji on a model of two circles with equal diameter and on the principle of a rotating hyperboloid ${ }^{26}$, the surface of which is sunken like a hyperbolic curve ${ }^{22,27}$. Maikala also describes significant relations between movements of the spine and vascular supply to intervertebral discs and muscles of the spine, including MES (ref. ${ }^{29,30}$ ). The intervertebral disc (IVD) has important mechanical functions such as spine load distribution and maintenance of flexibility. IVD degeneration represents a major pathological process in low back pain $^{29-32}$.

Correct function of MES plays a significant role in proper function of the entire deep stabilization system of the spine. It participates in spine stabilization during static load while seated or standing and also during dynamic load when the extremities are in motion; it allows transfer of forces and load from the area of upper and lower extremities, the pelvis and the upper torso.

The muscle stabilization system in the lumbar spine area comprises the major stabilizers latissimus dorsi m., gluteus maximus m., erector spinae m., biceps femoris m., exteral and internal oblique abdominal $\mathrm{m}$, rectus abdominis m., which secure direct segmental stability together with the pelvic floor muscles and the diaphragm ${ }^{32,33}$. These muscles are demonstrated in figures (Fig. 2,3) which are sequences of the one $3 \mathrm{D}$ exercise. Figures show anatomical muscle teamwork during phases of the movement $^{5,6,24}$.

\section{CORE training}

The term "CORE", i.e. the centre, in specialised terminology means muscles of the trunk in the area of the thoracic and cervical spine, in the lumbar area, area of pelvis and hips - the so called LPHC complex (lumbar-pelvichip complex). Any fast and sudden changes in the direction and position of the body are perceived as a change in balance. These approximately 26 muscles stabilize and provide control over all movements. In special athletic training the primary target is strengthening the "centre of the body"19-22. In this area, all movements are initiated and the body's centre of gravity - COG - is located here. Such athletic training leads to strengthening of the deep 


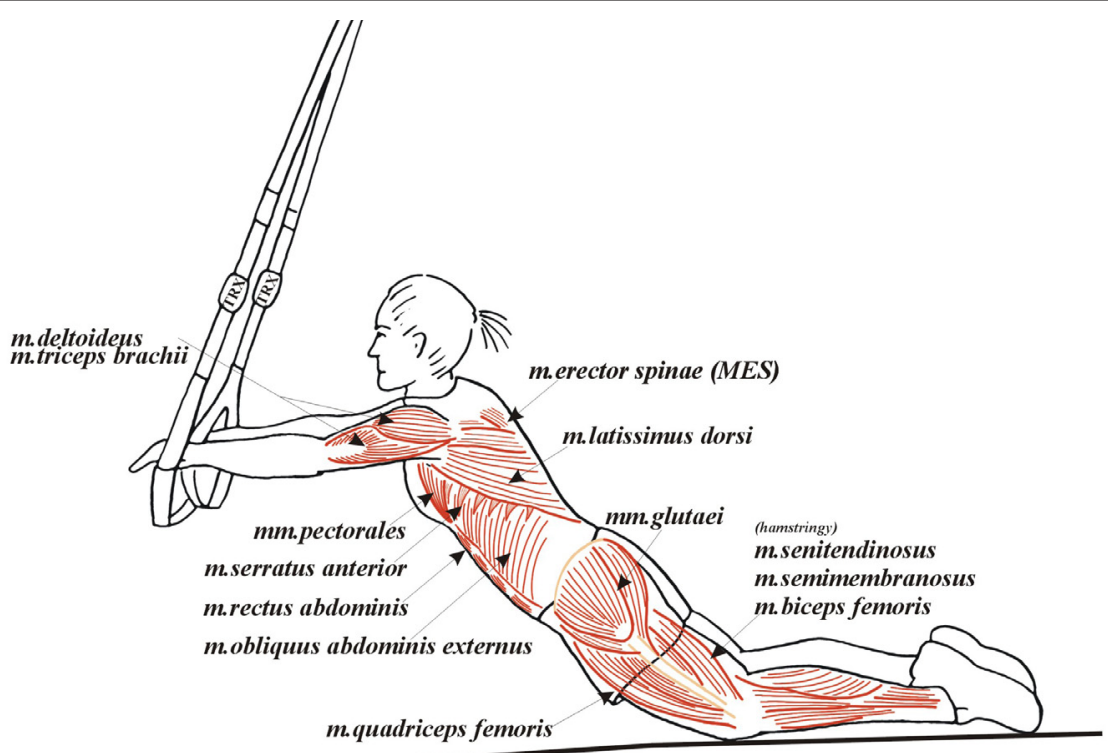

Fig. 2. Kneeling Roll Out.

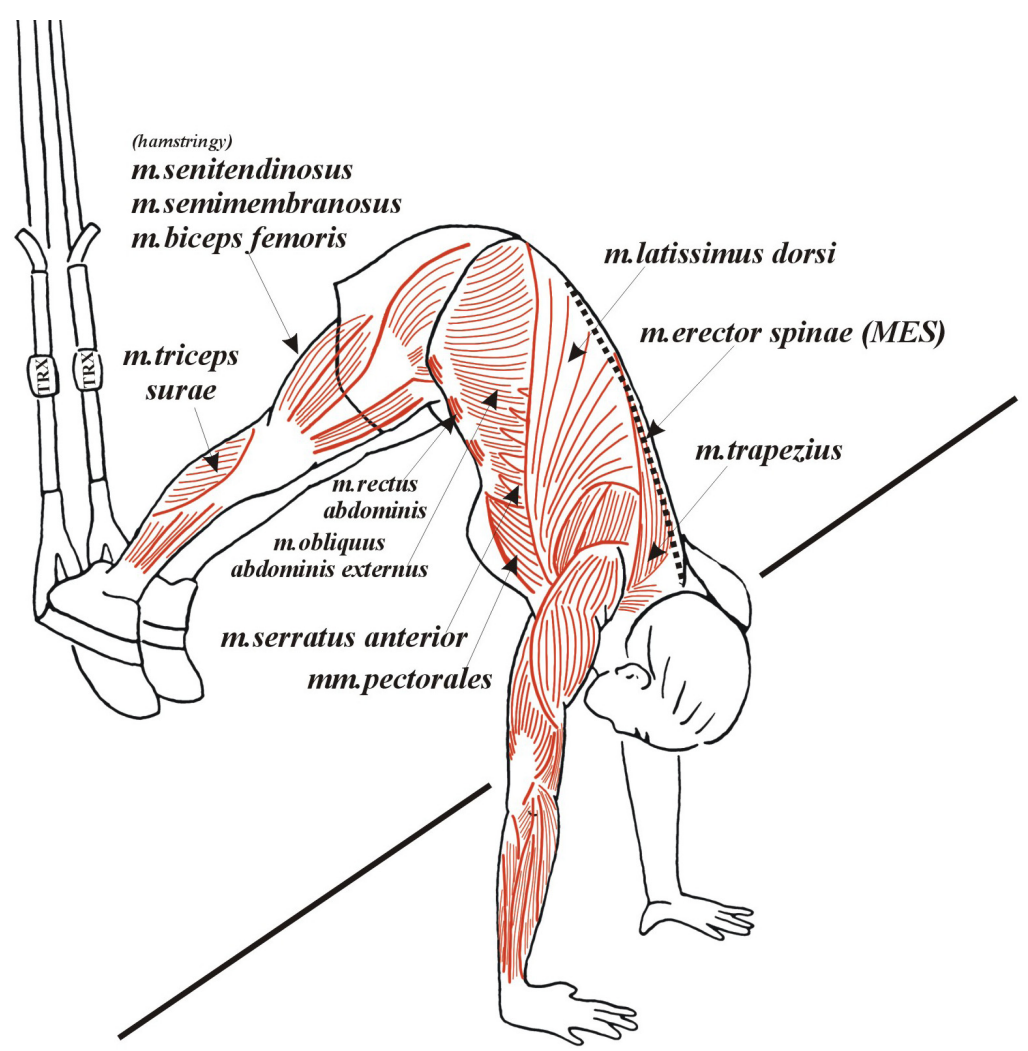

Fig. 3. Pike.

muscle system, i.e. muscles that are not often involved in common exercise. Core training also helps in preventing injuries during athletic as well as everyday movement, backaches, and it improves body posture ${ }^{23}$.

Core training is used by professional fitness trainers to render speed and strength abilities, which are reflected in repeated accelerations, more effective. A firm trunk should definitely not be omitted, as it plays a great role in preventing injuries and it is also beneficial in one's personal life. These exercises are focused on static muscle strengthening and compensations of muscle imbalances, mainly in the area of trunk, where the entire body is stabilized and remains in a balanced position for a period of $15 \mathrm{~s} / 30 \mathrm{~s} / 45 \mathrm{~s} / 60 \mathrm{~s}$.

As a result, the deep stabilization muscles are strengthened. In this way we also focus on strengthening phasic muscles, which have the tendency to slacken and we stretch postural muscles that tend to shorten ${ }^{35,36}$. 


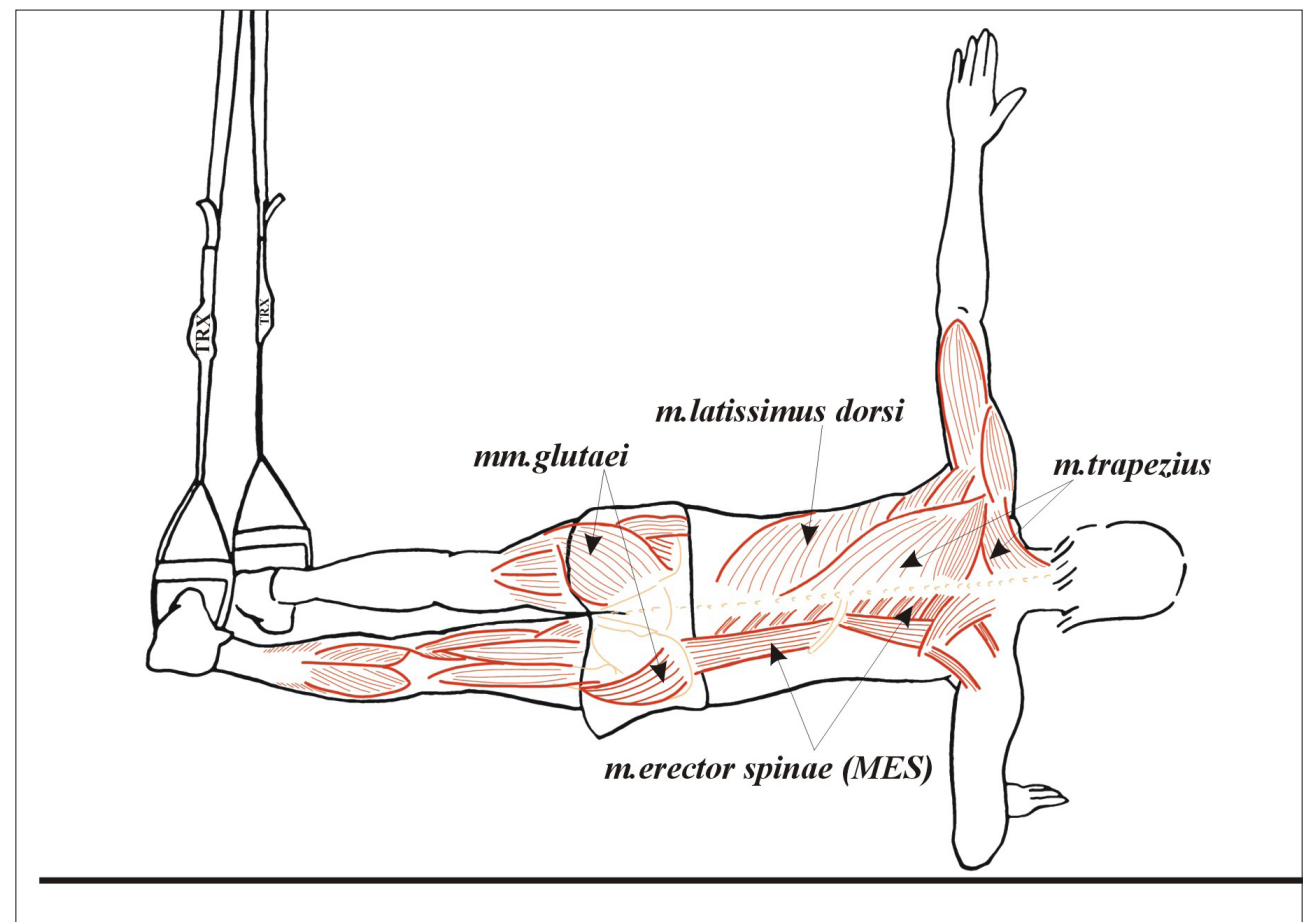

Fig. 4. Side Plank workout A.

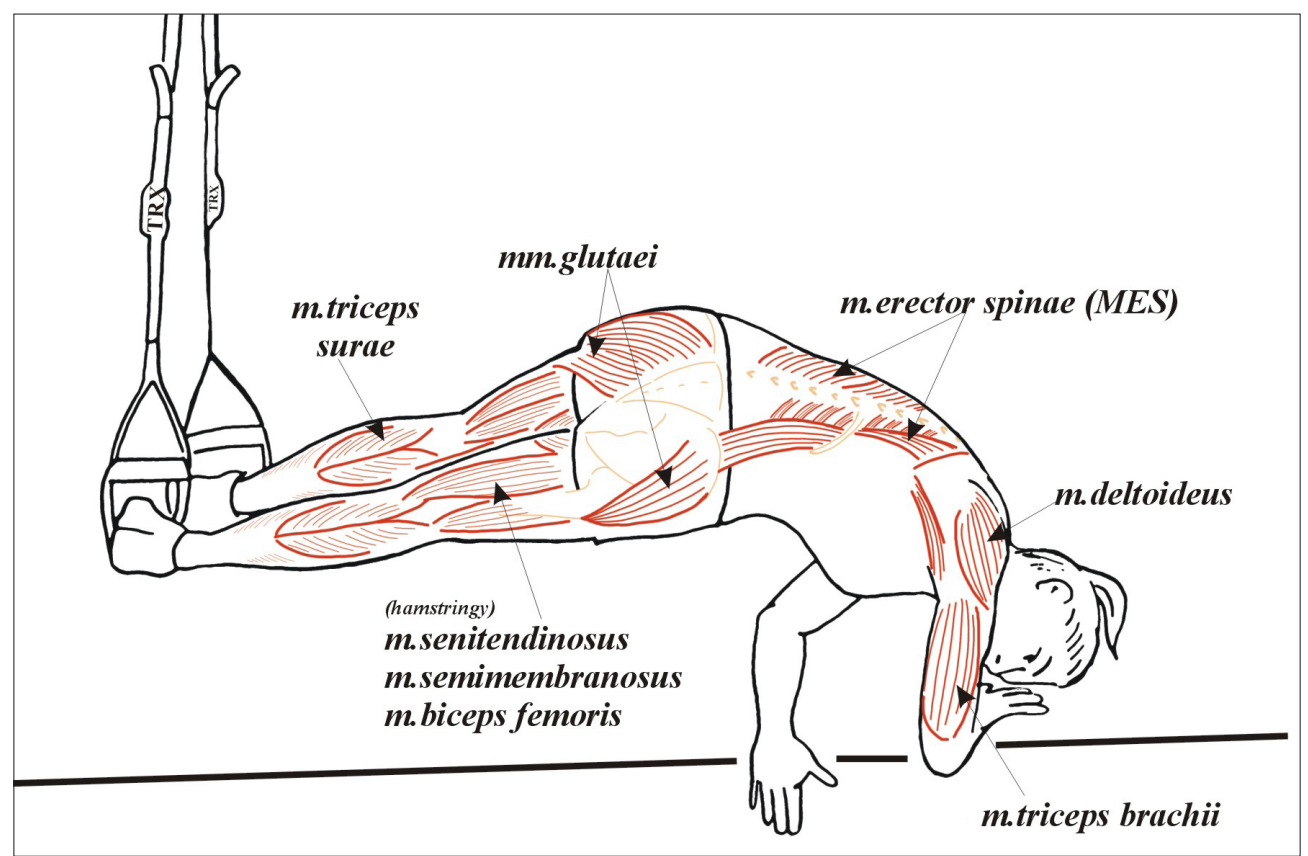

Fig. 5. Side Plank workout B.

\section{Training Resistance Exercise (TRX)}

The TRX system is a unique suspension system, which uses movement in all three planes for exercising with the possibility of adjusting the level of difficulty and the incorporation of additional balancing tools. Suspension training is characterized by one or more hands or feet supported by a single anchor point while the opposite end of the body is in contact with the ground. It uses your own body-weight as resistance and takes advantage of stability to load and unload exercises ${ }^{26}$. Resistance exercises performed in unstable body positions have been hypothesized to increase the muscular strength and muscular endurance of the core musculature, which may translate to more powerful and efficient movement patterns and less risk of
Indry ${ }^{7,22,34}$. Fig. 4,5 demonstrate upper limb and thorax in stable position but lower limb unstable additional in foot cradies of the TRX.

The entire system has great use, apart from in cardio and strength fitness training, mainly in smooth physiotherapy for muscle imbalance, disorders of knee stability, chronic "low back pain" conditions, strengthening the deep stabilization system of the body, strengthening the pelvic floor muscles and so on ${ }^{3,37-39}$.

The results of the three-month suspension training study of Yang on the diving athletes' shows, that balancing and core stability capacity were greatly improved, particularly in the non-stable state, which means the coordination of their internal muscle and the coordination between 
Table 1. Divisions of MES according to Terminologia Anatomica 1998.

\begin{tabular}{|c|c|c|c|}
\hline $\begin{array}{l}\text { Spinotransverse } \\
\text { system }\end{array}$ & & & \\
\hline $\begin{array}{l}\text { Sacrospinal } \\
\text { system }\end{array}$ & \multirow{3}{*}{ 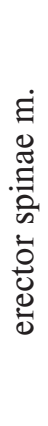 } & iliocostal m. & $\begin{array}{l}\text { lumbar part } \\
\text { thoracic part } \\
\text { cervical part }\end{array}$ \\
\hline \multirow{2}{*}{$\begin{array}{l}\text { Spinospinal } \\
\text { system }\end{array}$} & & longissimus $\mathrm{m}$. & $\begin{array}{l}\text { thoracic part } \\
\text { cervical part } \\
\text { capital part }\end{array}$ \\
\hline & & spinal m. & $\begin{array}{l}\text { thoracic part } \\
\text { cervical part } \\
\text { capital part }\end{array}$ \\
\hline \multicolumn{4}{|l|}{$\begin{array}{l}\text { Transverse-spinal } \\
\text { system }\end{array}$} \\
\hline $\begin{array}{l}\text { System of short } \\
\text { back muscles }\end{array}$ & & & \\
\hline
\end{tabular}

muscles were greatly improved ${ }^{40}$. At the same time, by testing the front and back vertical Jump, it is noted that the athletes' explosive force of lower limbs significantly improved. All the improvement in these abilities may have a direct impact on improving their special technical capabilities. The study showed that physical training based mainly on the suspension method is a new way of strength training and it is especially important for the skill-led events such as diving.

\section{CASE HISTORY}

A boy (L.B., 16 years of age) was examined at our paediatric obesitology outpatient department.

Subjectively: the patient complained of poor physical fitness, shortness of breath even during moderate exercise (longer walks over a straight terrain, walking up the stairs, etc.). He jad excessive perspiration frequent pains in both knee joints when idle (VAS3-4) and following physical activity (VAS 7).

Objective findings: obesitas magna, fine pink stretch marks on the abdomen and arms. Remaining somatic findings were physiological.

Anthropometric parameters: Height $185 \mathrm{~cm}$, weight: 104 kg, BMI: 30.4, waist $99 \mathrm{~cm}$, hips $114 \mathrm{~cm}$, Waist/hip ratio: 0.86 , arm circumference: $33 \mathrm{~cm}$, thigh circumference $66 \mathrm{~cm}$, chest circumference at max. inspiration: 110 $\mathrm{cm}$, chest circumference at max expiration: $105 \mathrm{~cm}$, (difference between chest circumference inspiration/expiration: $5 \mathrm{~cm}$ ), chest circumference at middle position: $108 \mathrm{~cm}$.

Locomotor apparatus examination: Relaxed posture when standing, head protuberant forward, shortened scalene muscles, shortened elevator scapulae muscle more significantly 1.dx, shoulders position in internal rotation- shortened pectoral muscles, asymmetric posi- tion of shoulder blades, shoulder blade elevation 1.dx, hypotonia of rhomboid muscles bilateral, hypotonia of ambdominal muscles, hyperlordosis of the $\mathrm{L}$ spine $(7 \mathrm{~cm})$ with shortened iliopsoas muscle bilateral (Thomayer 15 $\mathrm{cm}$ ), asymmetric position of the pelvis, shortened external hip rotator muscles - obturator mucsle, gemelli muscles bilateral and piriformis muscle bilateral. Shortened flexors of lower limb bilateral ( 55 degrees). Hypotonic gluteal muscles and significantly valgus in knees.

Due to joint pains of the lower limbs and the presence of functional disorders in the locomotor apparatus, we prepared an individual 8 week long training programme for the boy, including $45 \mathrm{~min}$ of functional training twice a week, with a combination of exercises, performed on TRX and Gravity, and walking twice a week with gradually extended time of up to $45 \mathrm{~min}$.

Once the training programme was completed, there was a significant objective improvement in physical fitness. The boy managed walking at a moderate pace for 45 min without feeling short of breath. He perspired less. He manages his common daily activities without any significant fatigue.

Anthropometric parameters:

Height: $186 \mathrm{~cm}$, weight: $97 \mathrm{~kg}$, BMI: 28, waist $89 \mathrm{~cm}$, hips $111 \mathrm{~cm}$, Waist/hip ratio: 0.8, arm circumference: 34 $\mathrm{cm}$, thigh circumference $65 \mathrm{~cm}$, chest circumference at max. inspiration: $109 \mathrm{~cm}$, chest circumference at max. expiration: $98 \mathrm{~cm}$, (difference between chest circumferences inspiration/expiration: $11 \mathrm{~cm}$ ), chest circumference at middle position $101 \mathrm{~cm}$.

Locomotor apparatus examination: Following training completion, the overall posture improved significantly, especially the slumping of the shoulder blade 1.dx (stretching of the levator scapulae muscle), stretching of pectoral muscles, symmetrical position of shoulders, strengthening of the interscapular muscles. The most significant effect was achieved according to Janda's muscle test by strengthening the deep stabilization system (erector spinae miscle). Lumbar lordosis was at borderline of physiological standard $(4 \mathrm{~cm})$. Stretching of the knee flexors (75 degrees). Strengthening of the abdominal wall.

\section{CONCLUSIONS}

Functional 3D training is an effective method for strengthening the postural muscles of the human body increasing articular stability, strengthening the ligaments and increasing the stability of muscle groups-especially of the back muscles during training for improving the lung capacity. The method of functional training is also of considerable significance in activating the pelvic floor muscles and the pelvic-trochanteric muscles for gynegymnastics and incontinence prevention in the falls in the case of patients with neurodegenerative diseases and in the therapy of obesity in children and adults. 


\section{ABBREVIATIONS}

3D, Three dimensional; COG, centre of gravity; $\mathrm{m}$., muscle; mm., muscles; L, lumbal; MES, erector spinae muscle; NASM, The National Academy of Sports Medicine; TRX, Training Resistance Exercise.

\section{REFERENCES}

1. Arráez-Aybar LA, Sánchez-Montesinos I, Mirapeix RM, MompeoCorredera B, Sañudo-Tejero SJ. Relevance of human anatomy in daily clinical practice. Relevance of human anatomy in daily clinical practice. Annals of Anatomy - Anatomischer Anzeiger 2010;192:341 8.

2. Moliková R, Bezdickova M, Langova K, Holibka V, David O, Michalikova Z, Rehorova J. The relationship between morphological indicators of human body and posture. Biomed Pap Med Fac Univ Palacky Olomouc Czech Repub 2006;150:261-5.

3. Robb Ch. TRX Counterfeits Fitness Anywhere Takes Action Against Dangerous TRX Counterfeits. [serial on the Internet]. 2010 Sep [cited 2011 Jul 05]; [about 4p.]. Available from: http://www.trxfitness.co.uk/ trx-counterfeits/.

4. Dylevský I. Funkční anatomie člověka. 1st ed. Praha: Grada; 2009.

5. Dylevský I. Speciální kineziologie. Praha: Grada; 2009.

6. Dylevský I. Základy strukturální kinezologie. Praha: Triton; 2009.

7. Panjabi MM. The stabilizing system of the spine. Part I. Function, imbalance, adaptation and enhancement, The stabilizing system. Part II. Neutral zone and instability hypothesis. J. Spinal disorders 1992;5:383-90;390-6.

8. Suchomel T, Lisický D. Progresivní dynamická stabilizace páteře. Rehabilitace a fyzikální lékařství 2004;3:128-36.

9. Sung PS, Lammers AR, Daniel P. Different parts of erector spinae muscle fatigability in subjects with and without low back pain. Spine J. 2009;9:115-20.

10. Kolář $P$, Lewit $K$. Význam hlubokého stabilizačního systému v rámc vertebrogenních obtíží. Neurologie pro praxi 2005;6:270- 5.

11. Yílmaz, F, Yílmaz A, Merdol F, Parlar D, Sahin F, Kuran B. Efficacy of dynamic lumbar stabilization excercise in lumbar microdiscectomy. J Rehabil Med 2003;35:163-7.

12. RenkawitzT, Linhart O, Grifka J. Electric efficiency of the erector spinae in high performance amateur tennis players. J Sports Med Phys Fitness 2008;48:409-16.

13. McKeon PO, Ingersoll CD, Kerrigan DC, Saliba E, Bennett BC, Hertel J. Balance Training Improves Function and Postural Control in Those with Chronic Ankle Instability. Med Sci Sports Exerc. [serial on the Internet]. 2008 Oct [cited 2011 Jul 05]; 40(10):[1810-9 p.]. Available from: http://www.nasm.org/hfpnpreview/article.aspx?id=2192\&te rms=functional+training

14. Schoffstall J E, Titcomb DA, Kilbourne BF. Electromyographic Response of the Abdominal Musculature to Varying Abdominal Exercises. Journal of Strength \& Conditioning Research 2010;24(12):3422-6.

15. Eckstein F, Hudelmaier M, Putz R, Eckstein F, Hudelmaier M, Putz R. The effects of exercise on human articular cartilage. J Anat 2006; 208:491-512.

16. Eckstein F, Faber $\mathrm{S}$, Muhlbauer $\mathrm{R}$, Hohe J, Englmeier $\mathrm{KH}$, Reiser $\mathrm{M}$, Putz R.. Functional adaptation of human joints to mechanical stimuli. Osteoarthr Cartilage 2002;10:44-50.

17. Hunter DJ, Eckstein F. Exercise and osteoarthritis. J Anat 2009;214:197-207.
18. Fitzgerald GK, Axe MJ, Snyder-Mackler L. The efficacy of perturbation training in nonoperative anterior cruciate ligament rehabilitation programs for physically active individuals. Physical Therapy 2000;80128-40.

19. Eliška O, Elišková M. Aplikovaná anatomie pro fyzioterapeuty a maséry. 1st ed. Praha: Galen; 2009. p.35-36; p.102-3.

20. Kučera M, Dylevsky I. Sportovní medicína. Praha: Grada; 1999.

21. Vele F. Kineziologie: Přehled klinické kineziologie a patokineziologie pro diagnostiku a terapii poruch pohybové soustavy. 2nd ed. Praha: Triton; 2006.

22. Verstegen M, Williams M. Core performance. 2nd ed. Carso: Rodile; 2008

23. Kott O. Předpoklady pohybu. 1st ed. Plzeň: Západočeská univerzita v Plzni, 2009. p7-9.

24. Čihák R. Anatomie 1. 2nd ed. Praha: Grada; 2001.

25. Terminologia Anatomica: International Anatomical Terminology FCAT/IFAA. New York: Thieme Medical Publishers; 1998.

26. Kapanji IA. The Physiology of the joints. Volume III. The Trunk And The Vertebral Column. 2nd ed. Edinburgh \& London \& New York: Churchill Livingstone, 1974. p15-17; p100-101; p112-113.

27. Aaras A, Fostervold IK, Ro O, Thoresen M, Larsen S, Postural load during VDU work: a comparison between various work postures. Ergonomics,1997;40(11):1255-68

28. Vagnerova M. Vývojová psychologie I-dětství, dospělost. 1st ed. Praha: Karolinum; 2005.

29. Loreto C, Musumecia G, Castorina A, Martinez G. Degenerative disc disease of herniated intervertebral discs is associated with extracellular matrix remodeling, vimentin-positive cells and cell death. Annals of Anatomy - Anatomischer Anzeiger 2011;193:156-62.

30. Maikala RV, Bhambhani YN. In vivo lumbar erector spinae oxygenation and blood volume measurements in healthy men during seated whole-body vibration. Exp Physiol 2006;91:853-66.

31. Stanford ME. Effectiveness of specific lumbar stabilization exercises: A single case study. The Journal of Manual \& Manipulative Therapy 2002;10:40-6.

32. Kendall PT, McCreary KE, Provance PG. Muscles: Testing and Function, with Posture and Pain: Includes a Bonus. Baltimore: Lippincott Williams \& Wilkins; 2005.

33. Cressey E, West C, Tiberio D, Kraemer W, Maresh C. The effects of ten weeks of lower-body unstable surface training on markers of athletic performance. Journal of Strength and Conditioning Research [serial on the Internet]. 2007 [cited 2011 Nov 21]; 21(2):561-7 [about 7 p.]. Available from: http://sport30ty.persiangig.com/12/THE\%20 EFFECTS\%20OF\%20TEN\%20WEEKS\%20OF\%20LOWER.pdf.

34. Boyle M. Functional training for sports. Champaign: IL Human Kinetics; 2004.

35. Chek P. Swiss ball exercises for swimming, soccer \& basketball. Sports Coach 1999;21:12-3.

36. Gambetta V. Let's get physio. For swim-specific weight training, get on the ball. It's easy with our simple but effective physioball routine. Rodale's Fitness Swimmer 1999;8:30-3.

37. Bettendorf B. TRX Suspension Training Bodyweight Exercises: Scientific Foundations and Practical Applications. San Francisco: Fitness Anywhere Inc.; 2010.

38. Evans N. Bodybuilding Anatomy. Leeds: Human Kinetics; 2007.

39. Pastucha $D$ et al. Pohyb v terapii a prevenci dětské obezity. Praha: Grada; 2011

40. Yang H, Li J, Shi Y. On Effect of Suspension Training Method for Physical Training of Diving Athletes. Journal of Capital Institute of Physical Education [serial on the Internet]. 2008 [cited 2011 Nov 21]; 06: [about 5 p.]. Available from: http://en.cnki.com.cn/Article_en/ CJFDTOTAL-BTSF200806019.htm 